\title{
Shear-Controlled Gold Mineralization of G. R. Halli Area of Chitradurga Schist Belt, Dharwar Craton: Insights from Fluid Inclusion Study
}

\author{
Govindappa Gopalakrishna ${ }^{1}$, Mohamed Shareef ${ }^{*}$, Poorigali Chowdaiah Nagesh ${ }^{2}$ \\ ${ }^{1}$ Geological Survey of India, NCEGR, Bengaluru, India \\ ${ }^{2}$ Department of Geology, Bangalore University, Bengaluru, India \\ Email:*shareefgeo@gmail.com
}

How to cite this paper: Gopalakrishna, G., Shareef, M. and Nagesh, P.C. (2018) Shear-Controlled Gold Mineralization of G. R. Halli Area of Chitradurga Schist Belt, Dharwar Craton: Insights from Fluid Inclusion Study. Open Journal of Geology, 8 , 662-673.

https://doi.org/10.4236/ojg.2018.87039

Received: April 4, 2018

Accepted: July 16, 2018

Published: July 19, 2018

Copyright $\odot 2018$ by authors and Scientific Research Publishing Inc. This work is licensed under the Creative Commons Attribution International License (CC BY 4.0).

http://creativecommons.org/licenses/by/4.0/

\begin{abstract}
Gold mineralization at G. R. Halli is located along the Central shear zone of Chitradurga schist belt, extending from west of Gonur, through east of G. R. Halli and C. K. Halli to east of Honnemardi, roughly parallel to stratigraphic units. The NNW-SSE trending shear zone has a width of 0.5 to $1.5 \mathrm{~km}$ shows extensive carbonatization of metabasalts and the associated lithologies confined to NNW-WNW trending arcuate brittle-ductile zone. The sheared and silicified contact zones between carbonaceous argillite and schistose metabasalt form the potential sites for localization of mineralization. The gold is associated with sulphides mainly pyrite, arsenopyrite, galena, sphalerite, minor chalcopyrite. Textural relationship indicates two stage sulphide mineral assemblages co-relatable with two stage fluid ascents having temperature of homogenization between $125^{\circ} \mathrm{C}$ and $256^{\circ} \mathrm{C}$. It is a typical epigenetic lode gold system, which got affected by later deformation.
\end{abstract}

\section{Keywords \\ G. R. Halli, Chitradurga Schist Belt, Dharwar Craton}

\section{Introduction}

Auriferous quartz vein occurrences from G. R. Halli were first reported by Bruce Foote [1] followed with reporting of ancient pits and dumps by Sambasiva Iyer [2], which yielded gold on panning. The first initiative for identification and delineation of mineralization potential of the area by Geological Survey of India was by Seshadri and Mallikarjuna [3], which led to establishment of G. R. Hall Central and NE area, with two auriferous lodes of gold and silver values as high 
as 4.1 to $10 \mathrm{ppm}$ and 5 to $44 \mathrm{ppm}$ respectively. The work was further carried out by Rajendran [4] and Rajendran and Khan [5]. They delineated two parallel to sub-parallel arcuate zones for gold mineralization. The mineralization is mainly shear controlled, epigenetic in nature, and has fluids that circulated at $2.5 \mathrm{~km}$ depth at temperature and pressure conditions of $241.27^{\circ} \mathrm{C}$ and $0.6 \mathrm{~Kb}$ respectively [6]. These fluid characteristics of G. R. Halli gold deposit indicate their Archaean lode gold deposit nature. In any Precambrian mineral deposit role of multiple deformation and fluid ascent cannot be ruled out. The study area has also witnessed intense carbonatization, resulting in culmination of primary features and overprinting of later activities. In view of this an attempt has been made in this paper to understand the role of deformation and nature of mineralization fluid through fluid inclusion signatures.

\section{Geological Setting and Mineralization}

Chitradurga schist belt (CSB) is an important greenstone belt of Dharwar craton and host number of gold occurrences along three major crustal scale shear zones viz., 1) Chitradurga Eastern Margin Shear Zone (CEMSZ), 2) Chitradurga Central Shear Zone (CCSZ) and 3) Chitradurga Western Margin Shear zone (CWMSZ). G. R. Halli deposit is a part of CCSZ (Figure 1) and exposes rocks belonging to Ingaldhal and Hiriyur Formation composed of schistose metabasalt and argillite-greywacke suite of rocks, intruded by irregular carbonated metabasic dykes and minor incidence of ferro-dolomite and lenses of quartz-goethite breccia (Figures 2-5). The area exhibits easterly younging succession with metabasalt of Ingaldhal Formation in the west and metasediments of Hiriyur Formation in the east. Metabasalts the dominant litho unit in the area and are fine grained, massive to schistose in nature, relatively more altered. Relict intergranular texture is defined by altered laths of plagioclase showing $\mathrm{v}$-junction development and chloritized pyroxene filling intergranular spaces. Very fine dissemination of magnetite, pyrite, pyrrhotite and chalcopyrite are noticed in metabasalt. Intense carbonatization of metabasalt has resulted in development of layering or banding in these rocks. Tension gashes are profusely developed in the area indicating role of shearing. Quartz-carbonate-sulphide veins are also seen traversing these litho units. Meta-argillites are very fine grained, dark grey laminated, carbonaceous rock. It shows alternating siliceous and carbonaceous layers. The siliceous layer is characterized mainly by presence of sericite with minor chlorite and quartz. The felsic volcanic is noticed in the northern and north eastern part of G. R. Halli village showing creamish grey colour, very fine grained, thinly foliated, friable and at places with variegated colour rock. The pervasive deformation fabrics $\left(S_{1}\right.$ and sub-parallel $S_{2}$ cleavages, trending NNW-SSE to NW-SE with sub-vertical dips) and mineral re-crystallization events (under greenschist facies conditions) are related to the late D1 and early D2 events. The latter D2 event also facilitated extensive granite plutonism in the regions around Chitraduraga, Jampannanaikanakote and Honnemaradi areas. 


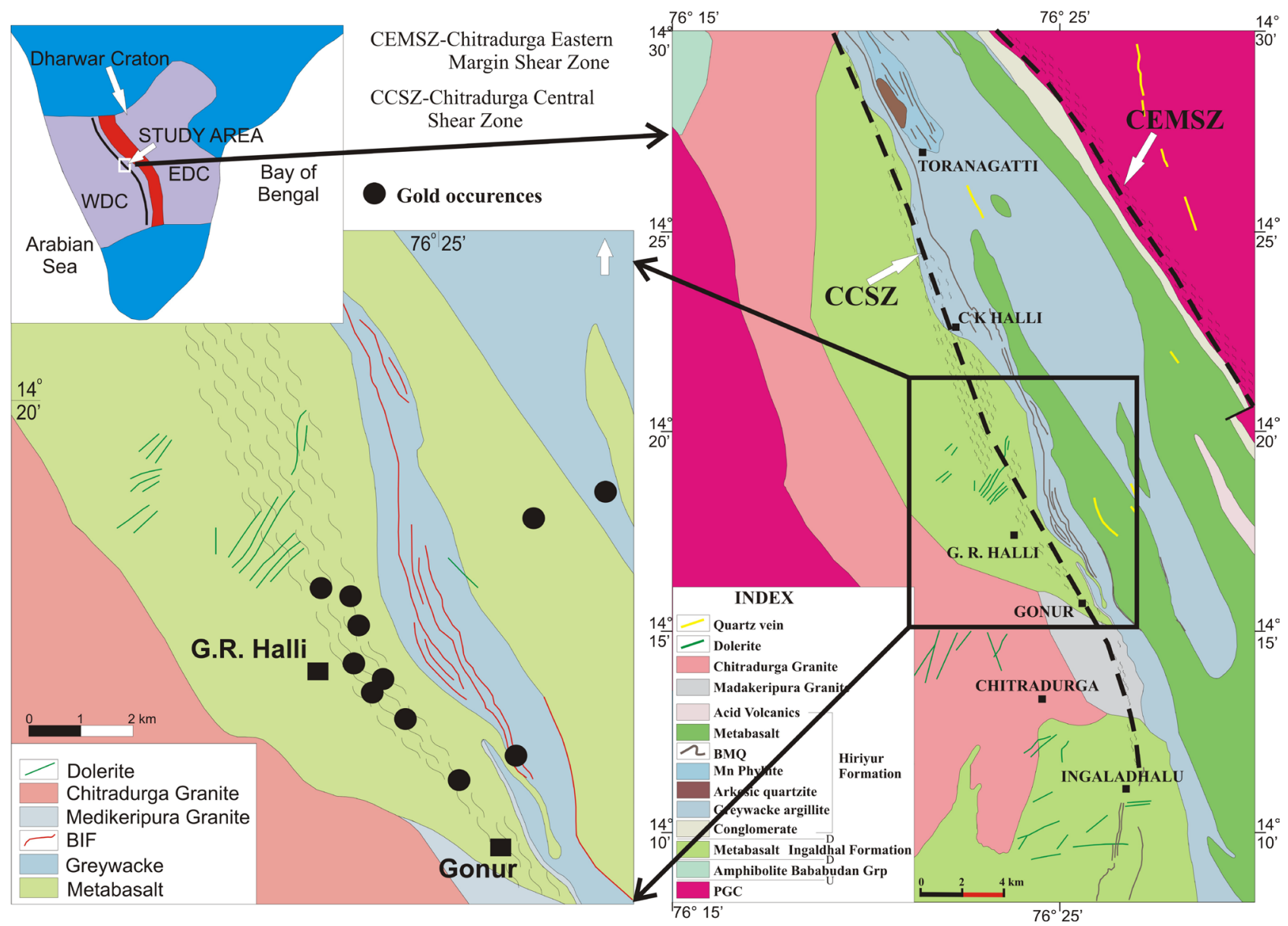

Figure 1. Geological map of the G. R. Halli, Chitradurga schist belt, showing shear corridor and gold occurrences [7].

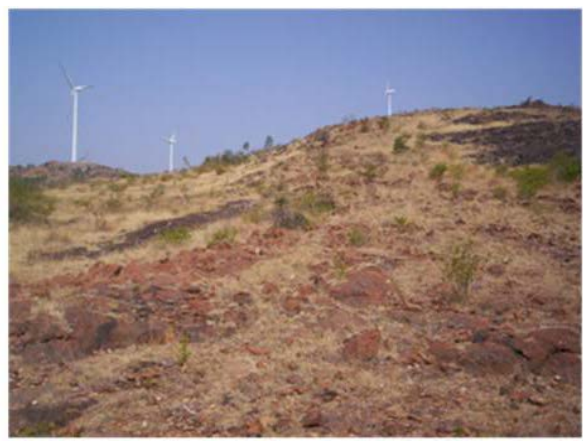

Figure 2. Field photograph showing carbonatized metabasalt outcrops.

The intrusive nature of these granites is demonstrated by presence of sharp contacts and veins and apophyses of granites in country rocks. The granites also contain xenolithic enclaves of country rocks.

Gold mineralization in this part of the Chitradurga schist belt is mainly confined to a major NNW-SSE trending shear zone extending from NW of Gonur towards C. K. Halli passing through east of G. R. Halli and M. N. Halli. Mineralization is normally sited in the shear zone/fault, contact of contrasting lithologies 


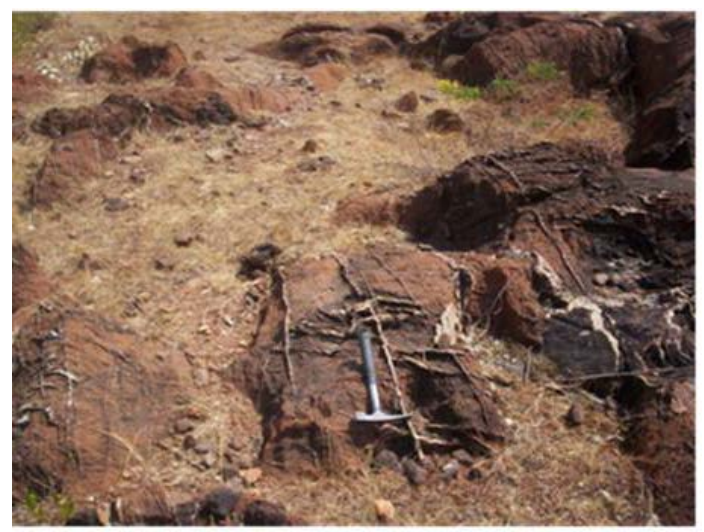

Figure 3. Field photograph showing metabasalt with tension gashes.

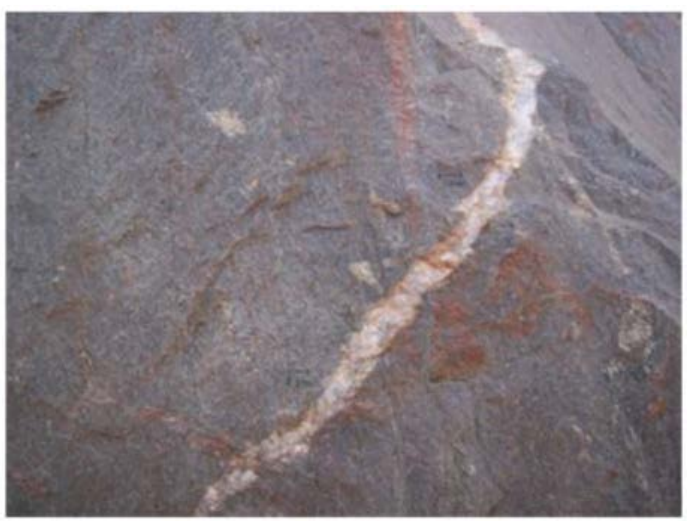

Figure 4. Field photograph showing quartz-carbonate veins in metabasalt.

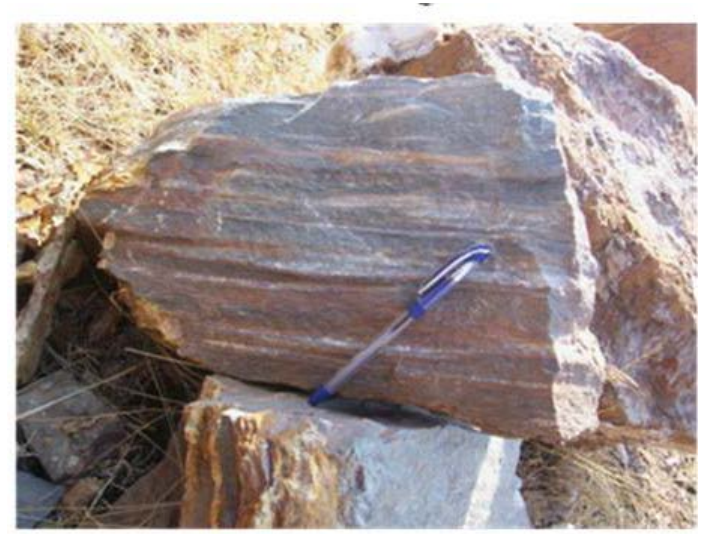

Figure 5. Field photograph showing layering in altered metabasalt.

and fold hinges. The mineralization is associated with quartz-ankerite veins emplaced at or near the contact of carbonated metabasalts with meta-argillites (Figures 6-8). The wall rock alteration mainly carbonatization, sericitization and chloritization are common around the mineralized zone [8]. These alterations 


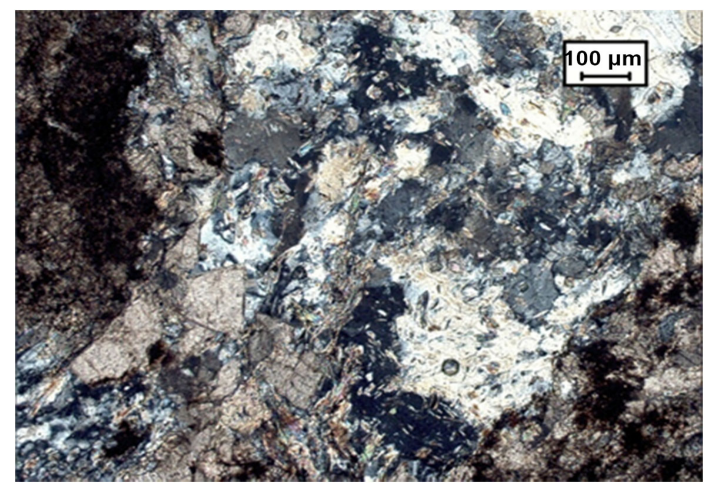

Figure 6. Photomicrograph showing quartz carbonate vein with chlorite.

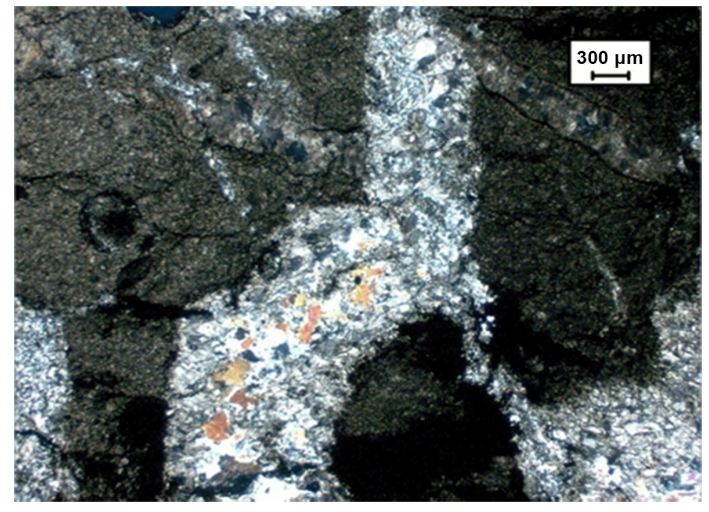

Figure 7. Photomicrograph showing secondary quartz carbonate veins in ankerite lense.

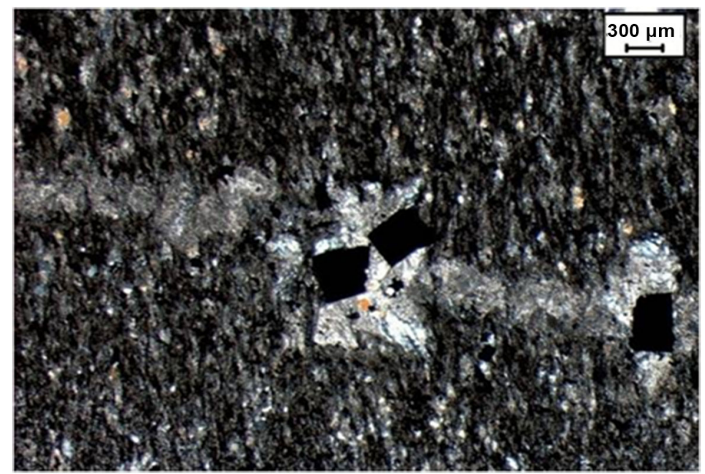

Figure 8. Photomicrograph showing association of euhedral arsenopyrite with quartz-carbonate vein in altered metabasalt.

are further classified depending on proximal to distal alteration by [9]. The gold mineralization occurs in the form of disseminations, stringers and fracture filling sulphides mainly pyrite, arsenopyrite, galena, sphalerite, minor chalcopyrite and rare stibnite associated with quartz-carbonate veins. Titano-magnetite is the main oxide facies minerals in the ore zones. Based on textural relationship between the sulphide minerals during the ore petrographic studies two-stage evo- 
lution is envisaged, where chalcopyrite, sphalerite and pyrrhotite association showing mutual boundary and exsolution textures define the first stage followed by arsenopyrite, pyrite, galena replacing the early sulphides (Figure 9).

\section{Fluid Inclusion Study}

Quartz veins samples traversing the metabasalt were selected for fluid inclusion study. These veins are invariably associated with mineralization. Quartz veins traversing the metabasalts vary from approximately 3 to $20 \mathrm{~cm}$. Mixed trails of aqueous-carbonic rich, bi-phase and carbonic monophase inclusions are observed predominantly within the undeformed quartz grains. These inclusions are of smaller size and show less equilibrated shapes in comparison to the primary fluid inclusions.

The shapes of the aqueous rich inclusions show a greater degree of equilibration than the corresponding monophase inclusions within single trails. A generalized picture of the disposition of the fluid inclusions is given. Both primary and secondary fluid inclusions were studied in order to understand the nature of fluids and role of subsequent deformation.

\subsection{Carbonic Monophase Inclusion}

Carbonic inclusions are filled with near pure liquid $\mathrm{CO}_{2}$. These mono-phase carbonic $\left(\mathrm{CO}_{2}\right)$ fluid inclusions are dark in colour. They are rounded and anhedral in nature. The size of these inclusions varies from 0.6 to $10 \mu \mathrm{m}$. Carbonic fluid inclusions are less abundant than aqueous carbonic inclusions in these samples. The melting temperature of $\mathrm{CO}_{2}$ ranges from $-56.7^{\circ} \mathrm{C}$ to $-59.1^{\circ} \mathrm{C}$ indicating that the fluid is dominated by $\mathrm{CO}_{2}$ only. The homogenization temperatures of $\mathrm{CO}_{2}$ range from $5.7^{\circ} \mathrm{C}$ to $22.1^{\circ} \mathrm{C}$. The density of the $\mathrm{CO}_{2}$ varies from 0.75 to $0.89 \mathrm{~g} / \mathrm{cm}^{3}$.

\subsection{Biphase $\left(\mathrm{H}_{2} \mathrm{O}+\mathrm{CO}_{2}\right)$ Inclusions}

These bi-phase $\mathrm{H}_{2} \mathrm{O}+\mathrm{CO}_{2}$ inclusions are the earliest inclusions and are primary with respect to the quartz formation. The fluid inclusion data recorded are presented in the Table 1. These inclusions are of various shapes from negative crystals to irregular and oval shape. In many cases, the $\mathrm{H}_{2} \mathrm{O}-\mathrm{CO}_{2}$ inclusions are coexisting with monophase $\mathrm{CO}_{2}$ inclusions. At places they exhibit necking and stretching probably indicating they have been affected by deformation (Figure 10). Co-existing vapor rich and liquid rich fluid inclusions are present indicating boiling condition of mineralizing environment (Figure 11).

The melting temperature of $\mathrm{CO}_{2}$ ranges from $-56.6^{\circ} \mathrm{C}$ to $-59.2^{\circ} \mathrm{C}$. The range of homogenization temperature varies from $125^{\circ} \mathrm{C}$ to $256^{\circ} \mathrm{C}$ (Figure 12), which corresponds to a salinity range of 1.97 to 11.93 wt.\% $\mathrm{NaCl}$ equivalent (Figure 13) as calculated using Linksys software (version 1.8) following the equations [10] [11] and [12]. Major component in aqueous phase is $\mathrm{NaCl} \pm \mathrm{KCl}$ in the fluid system. Depreciation in $\mathrm{Tm} \mathrm{CO}_{2}$ indicates the presence of minor amount $\mathrm{CH}_{4}$ 


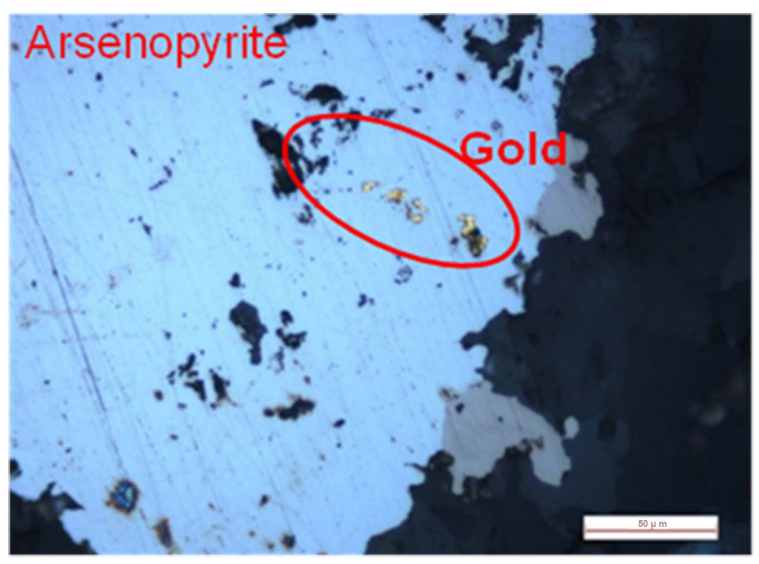

Figure 9. Photomicrograph showing gold within arsenopyrite replacing pyrrhotite.

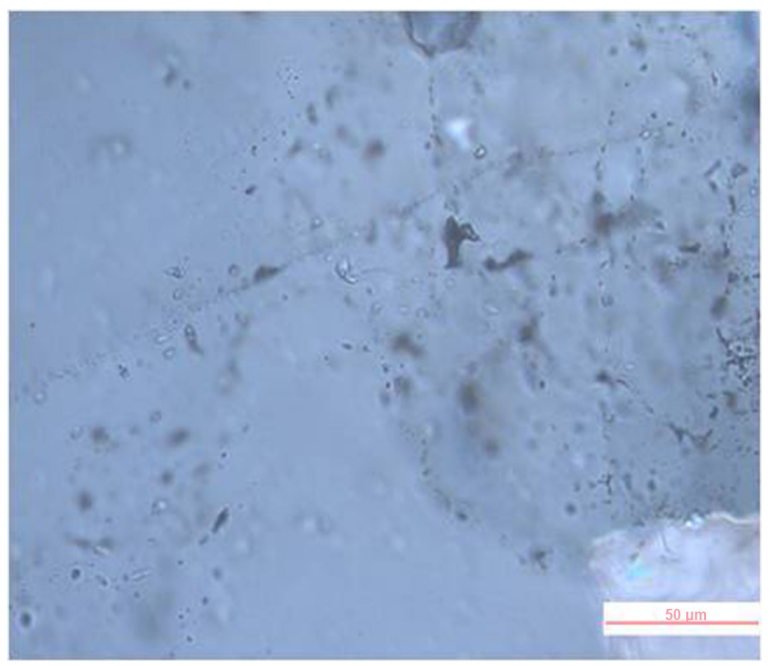

Figure 10. Photomicrograph showing secondary and deformed fluid inclusion.

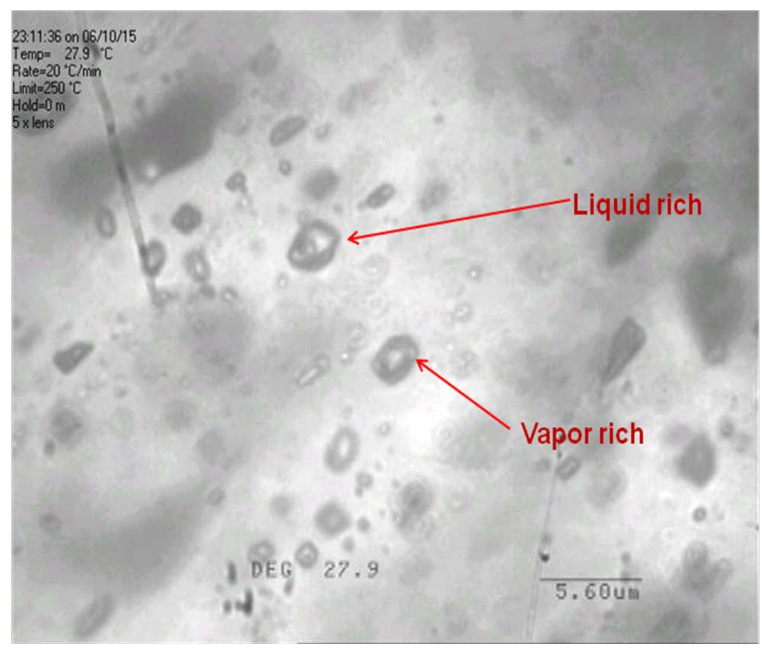

Figure 11. Photomicrograph showing co-existing vapor and liquid biphase $\mathrm{H}_{2} \mathrm{O}-\mathrm{CO}_{2}$ inclusions. 


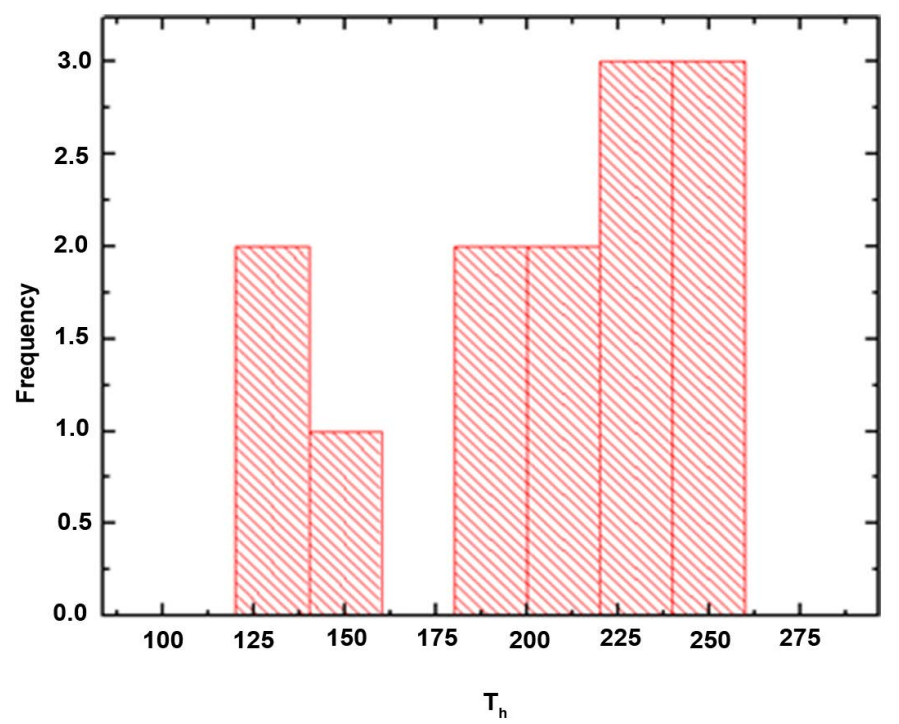

Figure 12. Histogram of temperature of homogenization (Th) for $\mathrm{H}_{2} \mathrm{O}-\mathrm{CO}_{2}$ inclusion.

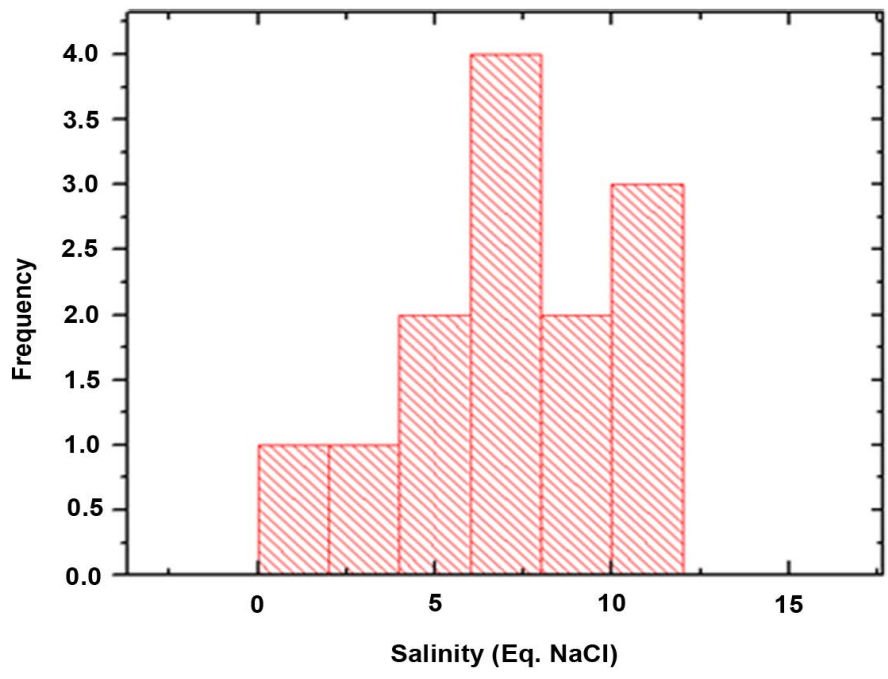

Figure 13. Histogram of Salinity for $\mathrm{H}_{2} \mathrm{O}-\mathrm{CO}_{2}$ inclusion.

Table 1. Fluid inclusion characteristics of $\mathrm{H}_{2} \mathrm{O}-\mathrm{CO}_{2}$ inclusions from the G. R. Halli area.

\begin{tabular}{cc}
\hline System & $\mathrm{H}_{2} \mathrm{O}-\mathrm{CO}_{2}$ \\
\hline Type & Primary \\
Shape & Irregular to rounded \\
Fill & Liquid + Vapor $(\mathrm{L}+\mathrm{V})$ \\
Temperature of melting of $\mathrm{CO}_{2}(\mathrm{Tm} \mathrm{CO})$ & 0.66 to 0.97 \\
Temperature of Ice melting $(\mathrm{Tm} \mathrm{Ice})$ & $-56.6^{\circ} \mathrm{C}$ to $-59.2^{\circ} \mathrm{C}$ \\
Th total & $-1.2^{\circ} \mathrm{C}$ to $-8.2^{\circ} \mathrm{C}$ \\
Phase & $125^{\circ} \mathrm{C}$ to $256^{\circ} \mathrm{C}$ \\
Wt $\%$ of NaCl equiv & Liquid $(\mathrm{L})$ \\
Density in gm $/ \mathrm{cc}$ & 1.97 to 11.93
\end{tabular}


in the $\mathrm{CO}_{2}$ bearing inclusions [13]. The $\mathrm{CO}_{2}$ density varies from 0.86 to 0.99 $\mathrm{gms} / \mathrm{cm}^{3}$. Pressure calculated from the Isochores of $\mathrm{CO}_{2}$ indicates a change in fluid pressure between 1200 and 2000 bars (Figure 14).

\section{Discussion and Conclusions}

Shear systems in Chitradurga schist belt have a distinct role as many of the known gold occurrences are situated along the three major shear zones viz., CEMSZ, CCSZ and CWMSZ. Litho units show evidences of shearing with overprinting carbonatization, sericitization and sericitization are seen in all the mineralized zones. Some of the earlier workers have opined two general associations of gold mineralization in CSB i.e., vein associated deposits mainly in metavolcanic rocks and stratiform-strata bound deposits in banded iron formation or Fe-rich cherts. In both the cases there is a distinct role of shear zone, which served as important conduits for the transfer of fluids and melts in the lithosphere. The occurrence of gold associated with vein systems and the localisation of the veins within faults/shear zones in G. R. halli area strongly suggest that structurally-focussed fluid flow was fundamental to the formation of this deposit.

Recently, based upon carbon and oxygen isotope data of carbonates from auriferous quartz carbonate veins magmatic/mantle source is proposed for the G. R. Halli gold deposits [14]. [9] indicated two events of hydrothermal activity by correlating the core and rim of the tourmaline with 1) the regional $\mathrm{D}_{1}$ deformational event associated with the emplacement of the adjoining ca. $2.61 \mathrm{Ga}$ Chitradurga granite and 2) juvenile magmatic accretion (2.56 to $2.50 \mathrm{Ga}$ ) associated with gold mineralization respectively. The two-event theory of [9] is clear-cut evidence that, the G. R. Halli area has been affected by multiple deformation and fluid ascent. This is further supported by present work on ore petrography with two distinct sulphide assemblages, i.e. early chalcopyrite, sphalerite and pyrrhotite association and later arsenopyrite, pyrite and galena association.

Fluid inclusion characteristics are also supportive of this where $T_{h}$ vs Salinity diagram clearly suggests that the second event has affected the early fluids resulting in re-equilibration (Figure 15). This is also supported by the clustering of two $T_{h}$ and the later is related to deformation in this case shearing. These fluid characteristics and co-relatable sulphide phases suggest that, there are two distinct fluid systems operated in the area where the early fluids having low saline mesothermal system were affected by later low temperature low to moderate saline fluid regime. Remobilization of gold and association of Ag with the second event cannot be ruled out with the given fluid system. Overall the G. R. Halli gold deposit is a typical epigenetic lode gold system, which got affected by later deformation. Epigenetic mineralisation is structurally controlled and normally sited in shear zones/fault, contact of contrasting lithologies and fold hinges. Alteration due to hydrothermal fluid interaction is characteristic of epigenetic type of mineralisation. Though alteration characteristics differ depending upon the 


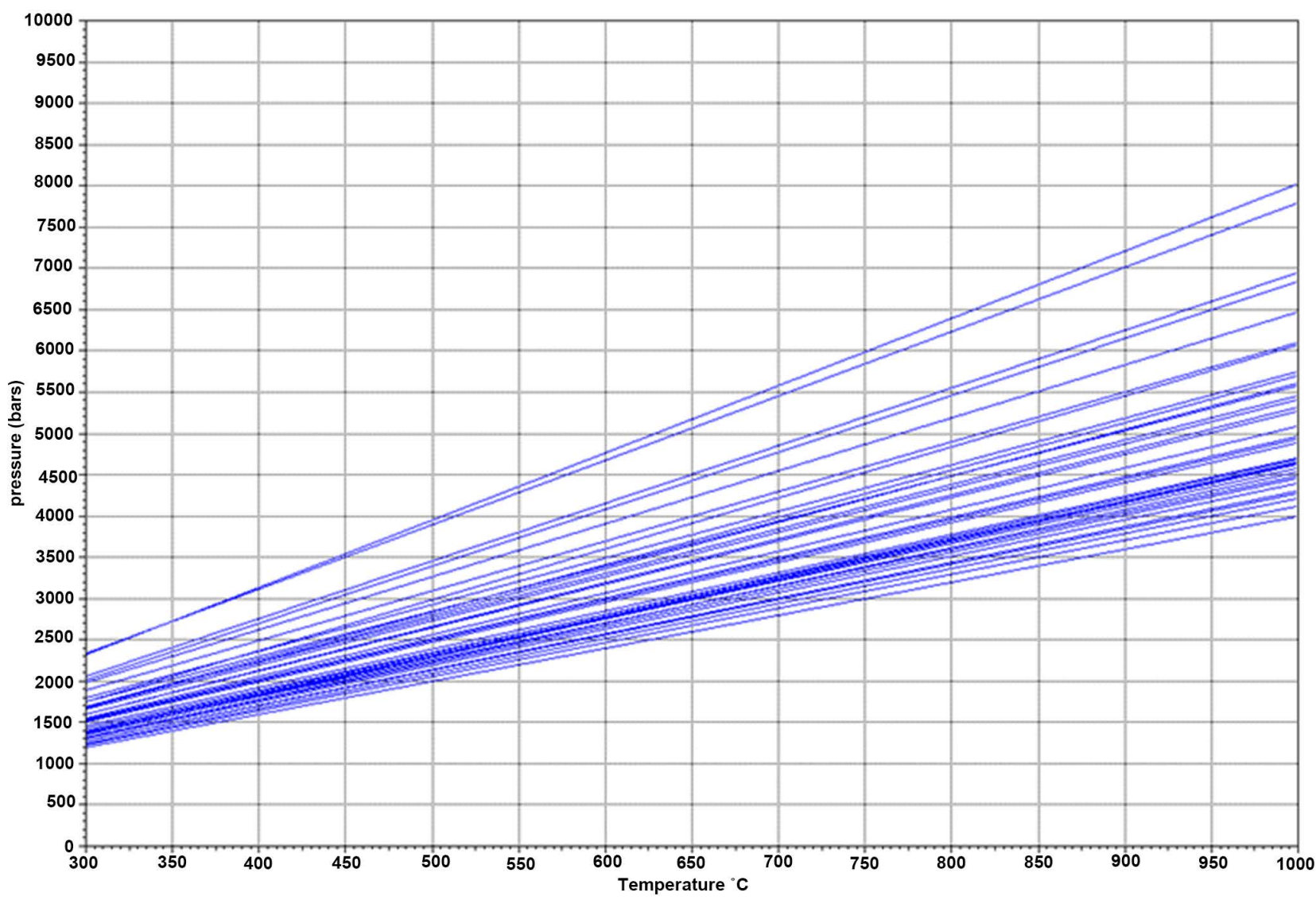

Figure 14. The isochors of carbonic inclusions is approximated by a $\mathrm{CO}_{2}$ system, revealing there was change in fluid pressures from 1200 to 2000 bars.

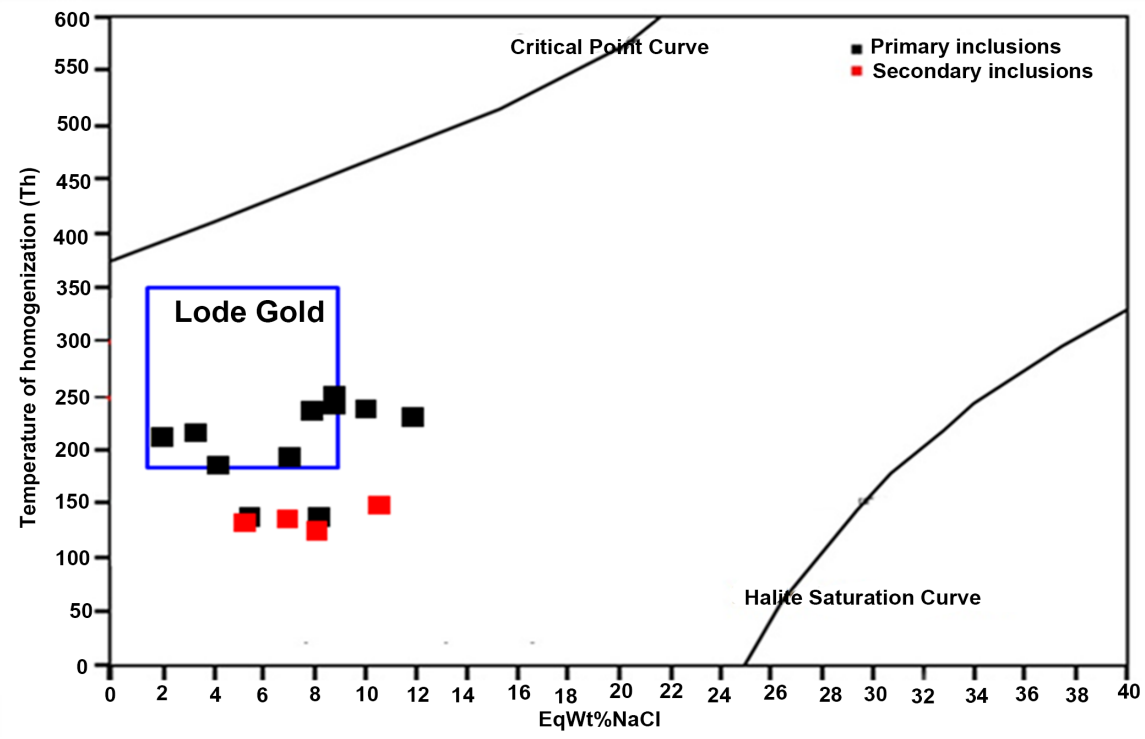

Figure 15. Salinity vs temperature of homogenization $\left(\mathrm{T}_{\mathrm{h}}\right)$ of samples from G. R. Halli area shows re-equilibration of early fluids later event.

host lithologies, the common manifestations include metamorphic retrogression and carbonatization. 


\section{Acknowledgements}

Authors are grateful to the Geological Survey of India (GSI), for granting permission to publish this paper. The authors are highly thankful to Shri. J. N. Das, Shri. R. P. Nagar and Shri. Subhasish Ghosh for support and encouragement for publication of this work. Authors also like to acknowledge all the fellow colleagues of GSI, Bengaluru for their fruitful discussion and support.

\section{References}

[1] Foote, B. (1888) The Dharwar System, the Chief Auriferous Series of South India. Records of the Geological Survey of India, 21, 40-56.

[2] Iyer, S. (1899) Memoirs of Mysore Geological Department, V. III, 1900-1901.

[3] Sheshadri, T.S. and Mallikarjuna, C. (1979) Progress Reports on Pilot Drilling for Base Metals and gold In G. R. Halli Section, Chitradurga Sulphide Belt, Chitradurga District, Mysore State. Unpublished Report of GSI for FS 1969-71.

[4] Rajendran, N. (1992) A Report on the Investigation for Gold in G. R. Halli-C. K. Halli, Honnumardi Areas, Chitradurga Schist Belt, Chitradurga District, Karnataka. Unpublished Report of GSI for FS 1989-90 and 1990-91.

[5] Rajendran, N. and Khan, S.A. (1994) A Report on the Investigation for Gold in G. R. Halli Central Block, Chitradurga District, Karnataka. Unpublished GSI Report for FS 1989-90 to 1991-92.

[6] Ananthanarayan, R. (2008) A Comparative Study on the Genetic Aspects of Gold Deposits of Karnataka (Gadag, Ajjanahalli, Chitradurga, Chinmalagund, Kempinkote and Kolar) through Fluid Inclusion Studies. Records of the Geological Survey of India, 140, 67-68.

[7] Khan, S.A. (1998) Final Report on Investigation for Gold in G. R. Halli South Block, Chitradurga Schist Belt. Unpublished Report of GSI for FS 1992-95.

[8] Khan, S.A. (2001) Gold Mineralization along Gonur-Jagalur Shear Corridor in Central Part of the Chitradurga Schist Belt, Karnataka. In: National Seminar on EXploration and Survey for Noble Metals and Precious Stones, Geological Survey of India Special Publication, Hyderabad, No.58, 251-261.

[9] Gupta, S., Jayananda, M. and Fareeduddin (2014) Tourmaline from the Archean G. R. Halli Gold Deposit, Chitradurga Greenstone Belt, Dharwar Craton (India): Implications for the Gold Metallogeny. Geoscience Frontiers, 5, 877-892. https://doi.org/10.1016/j.gsf.2013.12.004

[10] Bodnar, R.J. (1983) A Method of Calculating Fluid-Inclusion Volumes Based on Vapor Bubble Diameters and P-V-T-X Properties of Inclusion Fluids. Economic Geology, 78, 535-542. https://doi.org/10.2113/gsecongeo.78.3.535

[11] Zhang, Y.G. and Frantz, J.D. (1987) Determination of the Homogenisation Temperatures and Densities of Superficial Fluids in the System NaCl-KCl- $\mathrm{CaCl}_{2}-\mathrm{H} 2 \mathrm{O}$ Using Synthetic Fluids Inclusions. Chemical Geology, 64, 335-345. https://doi.org/10.1016/0009-2541(87)90012-X

[12] Brown, P.E. and Lamb, W.M. (1988) P-V-T Properties of Fluids in the System $\mathrm{H}_{2} \mathrm{O}-\mathrm{CO}_{2}-\mathrm{NaCl}$ : New Graphical Presentation and Implications for Fluid Inclusion Studies. Geochimica et Cosmochimica Acta, 53, 1209-1221. https://doi.org/10.1016/0016-7037(89)90057-4

[13] Swanenberg, H.E.C. (1979) Phase Equilibria in Carbonic Systems and Their Applications to Freezing Studies of Fluid Inclusions. Contributions to Mineralogy and 
Petrology, 68, 303-306. https://doi.org/10.1007/BF00371552

[14] Sarangi, S., Sarkar, A., Srinivasan, R. and Patel, S.C. (2012) Carbon Isotope Studies of Auriferous Quartz Carbonate Veins from Two Orogenic Gold Deposits from the Neo-Archean Chitradurga Schist Belt, Dharwar Craton, India: Evidence for Mantle: Magmatic Source of Auriferous Fluid. Journal of Asian Earth Sciences, 52, 1-11. https://doi.org/10.1016/j.jseaes.2012.02.004 